\title{
Wittlin for His “Late Grandchildren”: Initial Observations
}

Józef Wittlin was one of Poland's most gifted and admired novelists, essayists, and poets. He was born on August 17, 1896, in Dmytrów, Austria-Hungary (now Dmytriv, Ukraine) and died on February 28, 1976, in New York City. He belonged to a generation of exceptionally creative and original artists of Jewish origin who came of age within the borders of the Austro-Hungarian Empire and witnessed its downfall. Wittlin studied philosophy at the University of Vienna, where he befriended Joseph Roth. Their friendship was so strong that after the outbreak of World War I they decided to enlist in the army together; they ended up in the elite 21st Viennese Feldjäger battalion. Both wrote about the experiences of war as well as about the brutal collapse of the anachronistic structures of Austria-Hungary. Each of them left behind at least one masterpiece: Roth published Radetzky March, while Wittlin's great work was The Salt of the Earth. Roth's famous novel appeared in 1932, whereas Wittlin's opus magnum was published three years later, ${ }^{1}$ when Hitler was arming the Wehrmacht, and when the Nuremberg Laws, which stripped German Jews of citizenship and legal protection, began to be enforced. Perhaps that is why, despite folk-tale elements and the modeling of the novel after a Homeric epic, The Salt of the Earth is more frightening that Roth's work. Wittlin expressed his despairing pessimism and outlined an image of the world as "diabolical vaudeville."

This special issue of Konteksty Kultury is made available to readers to coincide with the one-hundredth anniversary of the end of World War I

1 The German translation of The Salt of the Earth could not have been published in the Third Reich. It was published by an émigré publisher (J. Witllin, Das Salz der Erde, Amsterdam: Allert de Lange, 1937). While in exile in Paris, Alfred Dőblin wrote an exceptionally positive review of the novel for a German language journal published in France - see: A. Döblin, "Ein polnischer Soldat Schweyk. Zu Joseph Wittlins Roman 'Das Salz der Erde,” Pariser Tageszeitung 1936, no. 139. 
and the publication of a new English translation of The Salt of the Earth. The texts presented here offer a variety of keys to understanding this novel. Dorota Siwor ("Where Is Piotr Niewiadomski Headed? The Protagonist of The Salt of the Earth in a Mythic--Ritual Context") argues that, by using the poetics of myth and the initiation model, the author not only demythologizes war, but also presents a diagnosis of the situation of European civilization on the eve of the cataclysm of World War II.

Meanwhile, Wojciech S. Woclaw ("The World as an Ironist's Playground: Reflections on Józef Wittlin's The Salt of the Earth") deals with one of the most important formal problems of the novel: the multifaceted irony, which illuminates but at the same time greatly hinders the deciphering of the author's intended meanings. In his essay "The Varieties of Religious Experience in Józef Wittlin's The Salt of the Earth," Łukasz Tischner analyzes the complicated problem of the writer's relationship with religion, a topic that is also central to Joanna Rzepa's text and the interview with Józef Wittlin's daughter Elżbieta Wittlin-Lipton. Joanna Rzepa ("Reinventing Saint Francis: Józef Wittlin, Anti-Semitism and the Idea of Modern Sainthood") has studied private notes, letters, poems, and essays in order to present Wittlin's long and convoluted path to Catholicism (the writer was baptized only in 1953). According to Rzepa, one of the most important questions that appear in these texts is whether "the Christian ideal of sainthood could be achieved in the century that had been scarred by growing political unrest, mass violence, technologically advanced warfare, and widespread anti-Semitism leading to the genocide of millions of European Jews." A crucial supplement to Rzepa's reflections is Elżbieta Wittlin-Lipton's testimony "Make It So That You Are': Łukasz Tischner Talks with Elżbieta Wittlin-Lipton," which confirms how important the figure of St. Francis was to her father. The writer's daughter also discusses the great hopes that Józef Wittlin had placed in Catholic-Jewish dialogue. She also recollects the circumstances of her father's death. The subject matter of this interview is related to Nina Taylor-Terlecka's essay "Wittlin Meets Death," which is a chronicle of the last weeks of the writer's life and recalls the reactions of Polish émigré communities to his passing. A colorful supplement to the essays collected here is Wojciech Ligęza's beautiful impression "The Mystery of Aviation," which shows Wittlin's literary craft, using the essay "Flight" as an example.

We are convinced that Wittlin's work forms a part of the canon of not only Polish, but also world literature in the twentieth century. That is why we have decided to publish this English-language issue on Wittlin consisting of essays that had previously been published in Konteksty Kultury. Because he had so much to say to his "late grandchildren" about human nature, the horrors of war, and the "disenchanted" world, it is our hope that the texts collected here will help readers to discover anew this partially forgotten brilliant writer. 